\title{
DESEQUILÍBRIOS CAMBIAIS E OS FUNDAMENTOS ECONÔMICOS: UMA ANÁLISE DO PLANO REAL*
}

\author{
Fernando Antônio Ribeiro Soares ${ }^{* *}$
}

\section{Maurício Barata de Paula Pinto ${ }^{* *}$}

RESUMO Este artigo analisa a evolução dos principais fundamentos econômicos brasileiros ao longo do período de rígida administração da taxa de câmbio no Plano Real. O trabalho tem início com uma resenha acerca dos fatores que causaram as instabilidades cambiais vividas pelo país nos anos 1990. As análises mostraram que os principais fatores eram os desequilíbRearios nos fundamentos econômicos, em especial nos fundamentos relativos às contas externas e fiscais. Dada tal condição, passou-se a analisar esses fundamentos. Os dados e construções realizadas mostraram que houve uma forte deterioração das variáveis relativas às contas externas e ao desempenho fiscal, confirmando os resultados apresentados pela literatura. Diante desses fatos, chegou-se à conclusão de que houve a formação de um círculo vicioso entre forte administração cambial, deterioração dos fundamentos e instabilidades cambiais.

Palavras-chave: administração da taxa de câmbio; Plano Real; desequilíbrios cambiais; fundamentos econômicos

Código JEL: F31, F41

* Artigo recebido em 27 de setembro de 2006 e aprovado em 19 de dezembro de 2007. Os autores agradecem os comentários feitos por Tito Belchior Silva Moreira. Os erros remanescentes são de responsabilidade dos autores.

** Técnico da Secretaria de Aviação Civil do Ministério da Defesa, e-mail: fernando.a.r.soares@ gmail.com

*** Professor da Universidade de Brasília, e-mail: mauriciopinto@unb.br 
EXCHANGE RATE IMBALANCES AND THE ECONOMIC FUNDAMENTALS:

\section{AN ANALYSIS OF REAL PLAN}

ABSTRACT This article analyzes the evaluation of the main Brazilian economics fundamentals during the period of fixed exchange rate regime in Real Plan. The paper begins with a survey regarding to factors that caused the foreign currency instability in this country in 90's. The analyze show that the main factors were the unbalanced economic fundamentals, specially the fundamentals regarding to external and fiscal accounts. Given this condition, these fundamentals were analyzed. The results analyzed based on data set and indicators of fundamentals show a strong deterioration of variables associate to external accounts and fiscal performance, confirming the results present by literature. In this context, we conclude that there was a vicious circle among a strict foreign currency management, deterioration of fundamentals and foreign currency instability.

Key words: management of exchange rate; Real Plan; exchange unbalanced; economic fundamentals 


\section{INTRODUÇÃO}

A economia brasileira experimentou durante o Plano Real um processo de rígida administração da taxa de câmbio (julho de 1994 a janeiro de 1999). Nesse período, em decorrência do próprio regime cambial, da condução da política econômica e das crises em escala global, o país foi acometido por diversos ataques especulativos. Em especial, o ataque contra a moeda brasileira, ocorrido em janeiro de 1999, acabou por forçar a flutuação cambial do real, substituindo o anterior regime de câmbio (quase) fixo.

Os fatos causadores desses desequilíbrios nos mercados cambiais, de acordo com a literatura, podem ser derivados de problemas nos fundamentos econômicos; ${ }^{1}$ dos custos (políticos) da manutenção de taxas de câmbio fixas ou fortemente administradas dentro de um ambiente de baixas taxas de crescimento econômico e de elevado desemprego ${ }^{2}$ e do efeito contágio proveniente de outras economias, ${ }^{3}$ entre outros possíveis modelos.

Analisar o modelo de crises do balanço de pagamentos que melhor se encaixa à realidade brasileira dos anos 1990 é o primeiro objetivo deste artigo. Nesse sentido, na primeira seção será realizada uma resenha cujo objetivo é demonstrar quais foram as principais causas daquela crise cambial. Desde já cabe ressaltar que a maioria dos autores aponta para desequilíbrios nos fundamentos macroeconômicos como geradores das instabilidades. Essa premissa, ou seja, que a crise cambial brasileira de janeiro de 1999 teve origem na deterioração dos fundamentos macroeconômicos, surge como um fato relevante para buscar explorar o comportamento desses fundamentos ao longo do período assinalado.

Dada a discussão do parágrafo anterior, tomar-se-á como condição que os desequilíbrios cambiais vividos pelo Brasil durante o Plano Real, e, em especial, durante a crise de janeiro de 1999, foram derivados de problemas nos fundamentos econômicos. Com base nessa premissa, será avaliada a evolução desses fundamentos ao longo do período proposto, com destaque para as variáveis relacionadas aos setores externo, fiscal e monetário. Pretende-se, dessa forma, verificar a ocorrência ou não da citada deterioração, e, caso se confirme, detalhá-la. Como um componente adicional do artigo, em sua última seção será analisado se em 1998, ano de eleições gerais, houve algum tipo de deterioração dos componentes macroeconômicos associada ao ciclo eleitoral. 
Feitas essas considerações iniciais, segue a estrutura do artigo. A primeira seção é dedicada à realização da resenha acerca dos fatores causadores das instabilidades cambiais no Brasil ao longo do Plano Real. Na segunda, terceira e quarta seções é analisada a evolução dos fundamentos relativos aos setores externo, fiscal e monetário, respectivamente. A quinta seção, por sua vez, enfoca mais uma vez os fundamentos econômicos, porém destacando o ano 1998, que corresponde a um ano de eleições gerais. Busca-se, dessa maneira, capturar, via comportamento dos fundamentos, se houve um ciclo eleitoral no período. Por fim, serão apresentadas algumas conclusões.

\section{ANÁLISE DA CRISE CAMBIAL BRASILEIRA: UMA RESENHA}

O objetivo desta seção é apresentar algumas contribuições da literatura econômica acerca do entendimento sobre a crise cambial brasileira dos anos 1990. Em particular, pretende-se expor, a partir da literatura existente, quais foram as causas da crise cambial ocorrida no Brasil. Ademais, buscar-se-á descrever, também a partir da literatura, quais foram as principais explicações para as pressões sofridas pela taxa de câmbio durante a experiência de taxas administradas.

Münch (1998) realiza um teste de credibilidade para a política cambial brasileira no período de 1994 a 1998. A autora analisa tanto a política de bandas cambiais quanto a política de intrabandas. De acordo com seus resultados, a banda cambial não se mostrou crível até a introdução da política de intrabandas, em meados de 1995. Porém, mesmo após a introdução das intervenções intramarginais, as bandas cambiais não foram consideradas críveis nos momentos das crises da Ásia e da Rússia. Quando a análise focou a política das intrabandas, rejeitou-se a hipótese de credibilidade da política cambial. A taxa de câmbio foi mantida na intrabanda artificialmente. De posse desses resultados, Münch sugere que a política cambial no período era muito suscetível a ataques especulativos e que o não-equacionamento de problemas relativos aos fundamentos econômicos do país, em especial na área fiscal, ampliava a vulnerabilidade da política.

Arbex e Fontes (1999) elaboraram um modelo para analisar a credibilidade das políticas econômicas brasileiras empreendidas entre os anos 1991 e 1998. O teste busca correlacionar as taxas de desemprego com o diferencial 
de taxas de juros entre o Brasil e os Estados Unidos. ${ }^{4}$ A hipótese central, conforme Arbex e Fontes (1999, p. 36), mostra que "desemprego alto e diferencial de juros também elevado seriam indicativos de que o público percebe o governo como sendo fraco e de pouca credibilidade, tendo em vista que seriam necessárias altas taxas de juros para assegurar a manutenção do regime cambial semifixo, num contexto onde o desemprego alto pode requerer a adoção de medidas expansionistas". Dada a premissa do modelo, os resultados para o período de julho de 1994 a junho de 1996 mostram que a política econômica era crível. Por outro lado, no período de julho de 1996 a junho de 1998 demonstrou-se a perda de credibilidade por parte do público na política econômica do país, sendo isso evidenciado em uma conjugação de elevado desemprego e tendência de crescimento no diferencial de taxas de juros.

Pastore e Pinotti (1999, 1999a) observam que a crise cambial brasileira de janeiro de 1999 deveu-se aos desequilíbrios nos fundamentos macroeconômicos do país, não sendo necessário desenvolver uma análise relativa ao modelo de expectativas auto-realizáveis. ${ }^{5}$ Os autores sustentam que a crise cambial foi derivada do crescimento não sustentável da dívida pública. Contribuíram para isso os vigorosos aumentos das taxas de juros reais necessários à defesa da taxa de câmbio quando dos sucessivos ataques especulativos enfrentados pelo país (México, Sudeste Asiático e Rússia). Pode-se considerar que houve uma gradativa deterioração dos fundamentos macroeconômicos que culminou com a crise cambial.

Schwartsman (1999), ao analisar os desequilíbrios cambiais vividos pelo Brasil nos anos 1990, descarta que o país estava incorrendo em crises autorealizáveis. Nesse sentido, o autor observa que, para o governo, diante de sua função perda, a importância da estabilidade econômica (o peso na função perda) era maior que os resultados negativos nos níveis de desemprego ou de crescimento econômico. Descartada a hipótese de crise auto-realizável, Schwartsman sinaliza que os problemas cambiais foram derivados primordialmente da deterioração da situação fiscal, o que reduziu a credibilidade da política monetária (realizada por meio da geração de diferenciais de taxas de juros) em manter a taxa de câmbio administrada e da sobrevalorização da taxa de câmbio real. ${ }^{6}$ 
Na visão de Averbug e Giambiagi (2000), a crise brasileira tinha características tanto dos modelos de fundamentos quanto dos modelos de crises auto-realizáveis. No que se refere aos problemas nos fundamentos, mais uma vez, foram indicados os desequilíbrios nas contas fiscais e externas. Já no que se refere aos modelos de crises auto-realizáveis, os autores apontam a falta de credibilidade do público nas políticas governamentais. Em relação ao primeiro motivo elencado estamos de acordo, porém, no que tange ao segundo, temos divergências. Em uma crise auto-realizável, o governante tem diante de si alternativas de política econômica. Obviamente, as alternativas possuem diferentes graus de liberdade em sua condução, bem como diferentes restrições econômicas e políticas para sua adoção. Tal situação, a nosso critério, não era verificada na economia brasileira quando da crise de janeiro de 1999, ou seja, o governo, debilitado em sua credibilidade, não possuía opções de política econômica, a não ser um vigoroso ajuste nas contas fiscais e externas, que, pelo seu início tardio, não foram suficientes para deter o overshooting cambial. ${ }^{7}$

A análise de Silva, Andrade e Torrance (2000) é voltada para a verificação da sustentabilidade dos planos de estabilização construídos com base na ancoragem cambial em um ambiente de liberalização e de intensificação dos fluxos financeiros mundiais. Foram avaliados o caso latino-americano e, em particular, o caso brasileiro. Os autores apontam que os desequilíbrios externos (provocados por persistentes déficits em conta de transações correntes) e fiscais validaram a corrosão da credibilidade do governo. Somados esses dois fatores, desequilíbrios nos fundamentos e perda de credibilidade, abria-se espaço para que o país estivesse sujeito ao efeito contágio. Pode-se, então, considerar que a existência de fundamentos deteriorados em um ambiente de alta volatilidade de capitais torna os países mais suscetíveis à recepção de ataques especulativos.

Com base na discussão de Silva, Andrade e Torrance, chega-se a uma importante conclusão: a defesa da âncora cambial diante de sucessivos ataques especulativos apenas adia a desvalorização da taxa de câmbio. Colocando em outros termos, a defesa da taxa de câmbio se dá, prioritariamente, pela geração de um substancial diferencial de taxa de juros. Tal medida, se bem-sucedida em repelir o ataque, tende a perpetuar os desequilíbrios em conta de transações correntes e a aprofundar os desequilíbrios fiscais. Con- 
seqüentemente, após a instabilidade cambial, os fundamentos tornam-se ainda mais deteriorados, fato que mina a credibilidade do governo e prepara o caminho para um círculo vicioso de ataques especulativos.

Andrade e Divino (2001) analisam a evolução da taxa de câmbio brasileira entre as décadas de 1970 e 1990, buscando identificar quais foram os fatores causadores das crises cambiais ocorridas no período. Como primeiros candidatos eles indicam os desequilíbrios nos fundamentos macroeconômicos (fatores fiscais e monetários, identificados a partir do crédito doméstico, e aqueles relativos à política cambial) e os fatores externos, em especial as variações nas taxas de juros internacionais e a ocorrência do efeito contágio. Em relação ao período compreendendo os anos 1994 a 1996, Andrade e Divino identificaram que a fonte dos desequilíbrios cambiais era o efeito contágio proveniente da crise mexicana.

Miranda (1999) usou os trabalhos de Flood e Garber (1984) e Ötker e Pazarbasioglu (1995) para identificar se variáveis representativas dos fundamentos macroeconômicos causaram instabilidades cambiais no Brasil entre 1982 e 1999. Para tanto, foi estimado um modelo probit. Os resultados obtidos não permitiram rejeitar a hipótese de que as crises cambiais e os ataques especulativos vividos pelo país foram derivados dos fundamentos macroeconômicos. Entre as variáveis que explicaram a probabilidade de ocorrência de desequilíbrios cambiais podem-se destacar a oferta de moeda, a taxa de câmbio fixada pelo governo, uma variável dummy representativa da liberalização do fluxo de capitais e o saldo da balança comercial.

Com base no modelo de Krugman (1979), Menezes e Moreira (2001) buscaram, por meio de testes de causalidade, avaliar se a crise cambial brasileira de janeiro de 1999 teve origem na deterioração dos fundamentos econômicos. Os autores testaram se a expansão do crédito doméstico precipitou o esgotamento das reservas internacionais e, portanto, levou à súbita mudança do regime cambial. Os resultados encontrados, no entanto, apontaram para a independência entre o crédito doméstico e as reservas internacionais. Conseqüentemente, não se pode atribuir à expansão do crédito doméstico a desvalorização cambial ocorrida no período. Tais resultados, entretanto, poderiam ser alterados caso fossem utilizadas outras variáveis representativas dos fundamentos. De acordo com nossa visão, variáveis relacionadas aos setores externo e fiscal são mais adequadas para testar os desequilíbrios observados na taxa de câmbio durante a década de 1990. 
O trabalho de Assis (2002) avalia o efeito contágio das crises do México, da Ásia e do Brasil, ocorridas, respectivamente, nos anos 1994, 1997 e 1999, para uma amostra construída a partir de dados de 22 países emergentes. Os resultados mostram que, para o caso brasileiro, o efeito contágio foi importante em deflagrar ataques especulativos. Porém, o próprio autor considera que em suas estimações, dado o baixo poder de explicação das regressões, foram omitidas variáveis relevantes, em especial as dívidas externa e interna, além de outras variáveis que inter-relacionam os fundamentos com os déficits em conta de transações correntes. Em conclusão, pode-se considerar que a não-inclusão de variáveis relativas aos componentes fiscal e externo diminui o poder de explicação dos resultados obtidos no artigo.

Menezes, Moreira e Souza (2005) realizam uma avaliação de crises cambiais ocorridas em nove países latino-americanos entre os anos 1992 a 1998. Em especial, foi aplicado o modelo de Velasco (1996) para verificar se as crises foram causadas por desequilíbrios nos fundamentos macroeconômicos ou se foram originadas em profecias auto-realizáveis. Foram construídas zonas de credibilidade, em número de três. São elas: a zona de credibilidade nula, a de credibilidade parcial e a de credibilidade total. Respectivamente tais zonas representam os seguintes resultados: crises derivadas de problemas nos fundamentos, profecias auto-realizáveis e inexistência de possibilidade de crise cambial. De acordo com as estimações realizadas, o Brasil, para o período analisado, se encontrava na zona de credibilidade nula. ${ }^{8} \mathrm{~A}$ interpretação desse resultado mostra-nos que os problemas cambiais enfrentados pelo país foram provenientes de desequilíbrios nos fundamentos econômicos.

Por fim, Soares (2006) e Soares, Pinto e Moreira (2006) analisam a experiência de administração da taxa de câmbio brasileira a partir do índice de pressão de fundamentos, que foi concebido para descrever o grau de deterioração (ou equilíbrio) dos fundamentos macroeconômicos de um país. Esse índice foi confrontado com o índice de pressão cambial, que, por sua vez, é uma medida que reflete a estabilidade (ou instabilidade) no mercado cambial. O relacionamento entre essas duas medidas, em particular no período prévio à crise cambial brasileira de janeiro de 1999, demonstrou forte associação, o que dá indícios de que os fundamentos deteriorados contribuíram para os desequilíbrios da taxa de câmbio no período. 
Dada a resenha apresentada no quadro 1, será apresentado um resumo acerca do que os diversos trabalhos assinalaram como prováveis causadores dos desequilíbrios cambiais vividos pela economia brasileira nos anos 1990.

De acordo com as informações dispostas no quadro 1, depreende-se que a maioria dos trabalhos acerca da experiência de forte administração da taxa de câmbio durante o Plano Real sinaliza para ocorrência de instabilidades nessa variável decorrente da deterioração dos fundamentos econômicos. Isso posto, nas seções que seguem será analisada a evolução dos principais fundamentos macroeconômicos brasileiros, buscando-se determinar o quanto estes se tornaram deteriorados ao longo do Plano Real e, dessa forma, o quanto podem ter contribuído para as instabilidades cambiais. Porém, antes de empreender essas análises, deve-se fazer uma digressão acerca do papel do modelo de inserção da economia brasileira na economia mundial ao longo dos anos 1990 como uma fonte adicional de desequilíbrios.

Deve-se considerar que dentro da literatura econômica há uma importante discussão acerca do modelo de inserção das economias emergentes, inclusive da economia brasileira, no mercado internacional a partir dos anos 1980 e $1990 .{ }^{9}$ De acordo com essa literatura, a liberalização da conta de capital e financeira do balanço de pagamentos e seus reflexos sobre os fluxos de capitais, inclusive, e, principalmente, o grande aumento da volatilidade dos capitais contribuíram para aumentar a vulnerabilidade dessas econo-

Quadro 1: Trabalhos e indicação do modelo de crise cambial

\begin{tabular}{ll}
\hline Trabalho & Tipo de crise cambial \\
\hline Münch (1998) & Desequilíbrio nos fundamentos. \\
\hline Arbex e Fontes (1999) & Crise auto-realizável. \\
\hline Pastore e Pinotti (1999, 1999a) & Desequilíbrio nos fundamentos. \\
\hline Schwartsman (1999) & Desequilíbrio nos fundamentos. \\
\hline Averbug e Giambiagi (2000) & Desequilíbrio nos fundamentos e crise auto-realizável. \\
\hline Silva, Andrade e Torrance (2000) & Desequilíbrio nos fundamentos e efeito contágio. \\
\hline Andrade e Divino (2001) & Efeito contágio. \\
\hline Miranda (1999) & Desequilíbrio nos fundamentos. \\
\hline Menezes e Moreira (2001) & Não conclusivo. \\
\hline Assis (2002) & Efeito contágio. \\
\hline Menezes, Moreira e Souza (2005) & Desequilíbrio nos fundamentos. \\
\hline Soares (2006) e Soares, Pinto e Moreira (2006) & Desequilíbrio nos fundamentos. \\
\hline Fonte: Elaborado pelos autores. &
\end{tabular}


mias. No caso brasileiro, essa vulnerabilidade teria se traduzido em uma série de ataques especulativos entre 1994 e 1999, sendo, neste último ano, precipitada uma crise do balanço de pagamentos acompanhada por uma crise cambial. ${ }^{10}$

\section{FUNDAMENTOS RELATIVOS ÀS CONTAS EXTERNAS}

O estabelecimento de um plano de estabilização utiliza como instrumento a administração da taxa de câmbio, ou seja, a âncora cambial pressupõe a fixação ou, pelo menos, a determinação de uma menor taxa de desvalorização quando comparada com o período anterior à adoção do plano. A menos que o diferencial entre a inflação interna e a externa seja inferior à taxa predeterminada de desvalorização cambial, inevitavelmente o programa gerará uma redução da taxa de câmbio real. Colocando em outros termos, caso a condição de paridade de poder de compra não seja assegurada, uma supervalorização cambial, e todas as suas conseqüências derivadas, ocorrerá. De fato, essa é uma regularidade verificada nas economias que adotaram planos de estabilização construídos a partir da ancoragem cambial.

A análise da evolução do mercado cambial brasileiro é, portanto, um importante ponto de partida. A seguir, com base em uma metodologia bastante simplificada, pretende-se determinar a supervalorização cambial ocorrida na economia brasileira. A abordagem terá início com a equação de paridade de poder de compra para a taxa de câmbio nominal ${ }^{11}$

$$
P=e P^{*}
$$

onde $P$ é o nível de preços interno, $e$ corresponde à taxa de câmbio nominal (R\$/US\$) e $P^{\star}$ representa os preços internacionais, em particular os preços norte-americanos. Linearizando e diferenciando a equação (1) e rearranjando os termos, é obtida a taxa de desvalorização cambial nominal

$$
\frac{\dot{e}}{e}=\frac{\dot{P}}{P}-\frac{\dot{P}^{*}}{P^{*}}
$$

onde $e / \dot{e}$ é a taxa de desvalorização cambial, $\dot{P} / P$, a taxa de crescimento dos preços internos, e $\dot{P}^{\star} / P^{\star}$, a taxa de crescimento dos preços internacionais. 
A equação (2) pode, portanto, ser reescrita da maneira que segue:

$$
\dot{e} / \mathrm{e}=\pi-\pi^{*}
$$

onde $\pi$ é a inflação brasileira e $\pi^{*}$ é a inflação norte-americana.

A equação (3) nada mais é do que uma simples representação da equação de poder de paridade de compra relativa (PPC relativa). Para que essa condição seja preservada, a desvalorização da taxa de câmbio nominal terá de ser igual ao diferencial entre a inflação brasileira e a norte-americana. Caso contrário, se a taxa de desvalorização cambial for superior ou inferior ao diferencial de inflação, teremos, respectivamente, uma desvalorização ou valorização real da taxa de câmbio.

Para verificar se o comportamento da taxa de câmbio nominal permitiu que fosse mantido o equilíbrio dos preços relativos entre as moedas, ou seja, que a condição de paridade de poder de compra relativa fosse mantida, deve-se calcular $\dot{e}$ /e na equação (3) como um resíduo e comparar com a efetiva desvalorização nominal ocorrida. Dessa forma, o próximo passo é obter os resultados relativos à equação $(4)^{12}$

$$
\hat{e}_{t}=\pi_{t}-\pi_{t}^{*}
$$

onde $t=1, \ldots, 56$, representa o período de junho de 1994 a janeiro de 1999, que, excetuando-se a observação de junho de 1994, corresponde ao período de administração de taxas de câmbio no Brasil.

A partir da estimação da equação (4), deve-se derivar a discrepância entre a taxa de câmbio nominal efetivamente praticada e a taxa de câmbio nominal que vigoraria caso a PPC relativa fosse mantida. De fato, a comparação se deu entre a taxa de crescimento da taxa de câmbio nominal (de/e) e a PPC relativa $(\hat{e})$, que, por construção, também representa uma taxa de crescimento. Com base nessa discussão, pode-se construir a equação que mensurará as variações na taxa de câmbio real:

$$
(d \theta / \theta)_{t}=\hat{e}_{t}-(d e / e)_{t}
$$

onde $(d \theta / \theta)$ é um indicador de supervalorização cambial. 
A equação (5) pode ser interpretada da seguinte maneira: quanto maior o resíduo inflacionário, ou diferencial, entre as taxas de inflação interna e internacional, em relação à taxa de desvalorização do câmbio nominal, maior será a valorização da taxa de câmbio real. Os possíveis resultados e seus efeitos sobre a taxa de câmbio real podem ser vistos no esquema a seguir.

Se $\hat{e}<($ de/e $) \rightarrow(d \theta / \theta)<0$, desvalorização da taxa de câmbio real

Se $\hat{e}=(d e / e) \rightarrow(d \theta / \theta)=0$, manutenção da PPC relativa

Se $\hat{e}>(d e / e) \rightarrow(d \theta / \theta)>0$, valorização da taxa de câmbio real

As comparações serão realizadas a partir de dois índices de preços: índice de preços por atacado (IPA) industrial e índice de preços ao consumidor (IPC). A escolha desses dois índices não foi aleatória e atendeu ao seguinte princípio: o IPA industrial, como não poderia ser diferente, é centrado em mercadorias comercializáveis e o IPC tem grande componente de bens não comercializáveis. Em tese, uma economia aberta comercialmente e sob o efeito da ancoragem cambial não deveria sofrer uma supervalorização cambial em termos do IPA industrial, sendo isso decorrente, principalmente, da competição proveniente das mercadorias importadas. Por outro lado, no que tange ao IPC, o resultado é o inverso, sendo a supervalorização proveniente do aumento dos preços dos bens não comercializáveis, que, por sua vez, não estão sujeitos à competição das importações.

Pode-se, então, considerar que o aumento dos preços dos bens não comercializáveis é o maior responsável pelo afastamento, ou desvio, da taxa de câmbio nominal da regra de poder de paridade de compra. Conseqüentemente, o diferencial inflacionário remanescente, apesar da instalação da âncora cambial, acabará por supervalorizar a taxa de câmbio real, sendo esse um fato estilizado dos planos de estabilização construídos a partir da administração da taxa de câmbio. A seguir será visto se esse fato foi confirmado para a economia brasileira.

Os resultados da realização da equação (5) demonstram que, em ambos os casos, IPA industrial e IPC, o diferencial de inflação, no início da série, é superior à taxa de desvalorização cambial. Tal situação para o IPA industrial persiste até início de 1995, quando o Brasil é atingido pelos efeitos da crise mexicana. Desse ponto em diante há uma tendência de convergência entre a taxa de desvalorização cambial e o diferencial inflacionário do IPA indus- 
trial. Essa análise corrobora as indicações anteriores, quando foi dito que em economias abertas com âncoras cambiais há uma tendência de convergência entre os preços internos e externos dos bens comercializáveis. A superioridade do diferencial inflacionário do IPC em relação à desvalorização cambial, por outro lado, mostrou-se mais resistente. Em seguida, será detalhado o comportamento da taxa de câmbio real durante o Plano Real. Em especial, serão construídas algumas estimativas de supervalorização cambial. Iniciando pelo IPA industrial, na tabela 1 serão resumidas as principais informações das variações na taxa de câmbio real obtidas a partir desse índice.

Os dados confirmam a supervalorização cambial sofrida pela taxa de câmbio brasileira ao longo do Plano Real. Também é confirmada a tendência, a partir do IPA industrial, de uma maior valorização real no início do plano de estabilização, mas com tendência de convergência (redução da supervalorização) à medida que a série evolui. Ao final, em dezembro de 1998, perdura ainda uma supervalorização real de 11,62\%. Os dados, no entanto, são substancialmente alterados quando é excluída a informação referente a julho de 1994. Deve-se realizar esse exercício com o intuito de expurgar a inflação sofrida pelo IPA industrial (18,45\% para esse período assinalado), dado que tal patamar de inflação não é derivado do Plano Real, mas do padrão monetário anterior. O resumo desse exercício é disposto na tabela 2.

Os dados demonstram que o expurgo da inflação referente a julho de 1994 faz com que haja uma aceleração na convergência entre a inflação interna e a internacional, no caso da inflação norte-americana. Os resultados demonstram inclusive que, antes da crise cambial de janeiro de 1999, já havia uma desvalorização real da taxa de câmbio elaborada com base no IPA

Tabela 1: Valorização/desvalorização acumulada da taxa de câmbio real (IPA), períodos selecionados entre julho de 1994 e dezembro de 1999 (\%)

\begin{tabular}{lccc}
\hline Período & Total & Período & Ano \\
\hline 071994 a 121994 & 33,69 & 1994 & 33,69 \\
\hline 071994 a 121995 & 26,98 & 1995 & $-5,02$ \\
\hline 071994 a 121996 & 20,11 & 1996 & $-5,41$ \\
\hline 071994 a 121997 & 17,35 & 1997 & $-2,30$ \\
\hline 071994 a 121998 & 11,62 & 1998 & $-4,88$ \\
\hline 071994 a 011999 & $-58,01$ & & \\
\hline
\end{tabular}

Fonte: Elaborada pelos autores a partir de dados do Banco Central do Brasil e do Fundo Monetário Internacional. Detalhes adicionais podem ser vistos em Soares (2006).

Nota: Um valor positivo indica uma valorização real da taxa de câmbio. 
industrial. De posse dessas construções, pode-se concluir que a suposição teórica do atrelamento da inflação interna relativa aos bens comercializáveis à inflação internacional quando de uma ancoragem cambial foi confirmada para o caso brasileiro durante o Plano Real.

Agora será desenvolvida a análise para o IPC. O primeiro elemento que deve ser considerado é a importante participação de bens não comercializáveis na construção desse índice, fato que contribui para a geração de diferenças entre os seus resultados e aqueles obtidos a partir do IPA industrial. As informações contidas na tabela 3 confirmam o comportamento da taxa de câmbio real em planos de estabilização implementados a partir da âncora cambial. Em outras palavras, os dados confirmam o fato estilizado de que em âncoras cambias existe uma natural tendência à supervalorização cambial, o que pode ser considerado como um dos fatores responsáveis pela geração de crises cambiais e, por vezes, pela própria destruição dos planos de estabilização. Não é exagero concluir que uma âncora cambial, instrumento que possui apelo político muito forte por não afetar, a princípio, o crescimento econômico, quando comparado com planos assentados em metas monetárias e fiscais, tem, obviamente, o momento de sua instalação, mas também tem, quase que necessariamente, o momento de seu abandono. Como se dá o seu abandono e seus reflexos sobre a economia, e em particular para o caso brasileiro da década de 1990, transcende o escopo deste artigo, mas trata-se de uma importante área de investigação.

Voltando-se aos resultados, verifica-se uma importante supervalorização cambial entre 1994 e 1995, ficando a mesma em torno de 30 a 35\%. Após esse período, inicia-se uma reversão do processo. Contribuiu para isso o

Tabela 2: Valorização/desvalorização acumulada da taxa de câmbio real (IPA), períodos selecionados entre agosto de 1994 e janeiro de 1999 (\% )

\begin{tabular}{lccc}
\hline Período & Total & Período & Ano \\
\hline 081994 a 121994 & 11,83 & 1994 & 11,83 \\
\hline 081994 a 121995 & 6,22 & 1995 & $-5,02$ \\
\hline 081994 a 121996 & 0,47 & 1996 & $-5,41$ \\
\hline 081994 a 121997 & $-1,84$ & 1997 & $-2,30$ \\
\hline 081994 a 121998 & $-6,63$ & 1998 & $-4,88$ \\
\hline 081994 a 011999 & $-64,88$ & & \\
\hline
\end{tabular}

Fonte: Elaborada pelos autores a partir de dados do Banco Central do Brasil e do Fundo Monetário Internacional. Detalhes adicionais podem ser vistos em Soares (2006).

Nota: Um valor positivo indica uma valorização real da taxa de câmbio. 
processo da gradativa, mas lenta, desvalorização cambial nominal. De acordo com os dados, a desvalorização média nos anos 1996, 1997 e 1998 foi de, respectivamente, 0,56, 0,60 e 0,66. Em relação ao ano 1998, cumpre ressaltar que nesse período já devem ser incorporados os efeitos das crises asiática e russa. Também não se pode descartar como fonte para a redução, mas não eliminação da supervalorização cambial, a queda dos índices de preço ao consumidor. Porém, no momento anterior à crise de janeiro de 1999, a valorização real ainda apontava para o significativo $16 \%$.

Finda a avaliação da taxa de câmbio real ao longo do Plano Real, restanos relacioná-la com alguns fundamentos macroeconômicos representativos das contas externas. Particularmente, procurar-se-á mostrar indícios de que a supervalorização cambial causou resultados negativos na balança comercial e, por conseqüência, na conta de transações correntes. A seguir é apresentado o relacionamento entre exportações, importações e saldo em conta de transações correntes.

Com base no gráfico 1, pode-se concluir que tanto as exportações quanto as importações apresentam uma tendência crescente ao longo da série. Porém, as exportações se mantiveram superiores às importações até o último trimestre de 1994, quando há uma inflexão nesse comportamento. Vários fatores podem explicar o aumento das importações: (i) o crescimento da renda real proporcionada pela estabilidade econômica permitiu o aumento da absorção e, conseqüentemente, das importações; (ii) a existência de uma demanda reprimida por mercadorias importadas, ou seja, houve uma descompressão do coeficiente de importações, e (iii) dada a credibilidade limitada no plano de estabilização, houve substitutibilidade entre con-

Tabela 3: Valorização/desvalorização acumulada da taxa de câmbio real (IPC), períodos selecionados entre julho de 1994 e dezembro de 1999 (\%)

\begin{tabular}{llcc}
\hline Período & Total & Período & Ano \\
\hline 071994 a 121994 & 30,78 & 1994 & 30,78 \\
\hline 071994 a 121995 & 36,30 & 1995 & 4,22 \\
\hline 071994 a 121996 & 35,80 & 1996 & $-0,37$ \\
\hline 071994 a 121997 & 30,27 & 1997 & $-4,07$ \\
\hline 071994 a 121998 & 16,18 & 1998 & $-10,82$ \\
\hline 071994 a 011999 & $-58,02$ & & \\
\hline
\end{tabular}

Fonte: Elaborada pelos autores a partir de dados do Banco Central do Brasil e do Fundo Monetário Internacional. Detalhes adicionais podem ser vistos em Soares (2006).

Nota: Um valor positivo indica uma valorização real da taxa de câmbio. 


\section{Gráfico 1: Exportações, importações e saldo em conta de transações correntes (US\$ milhões), T1/1992 - T4/1994}

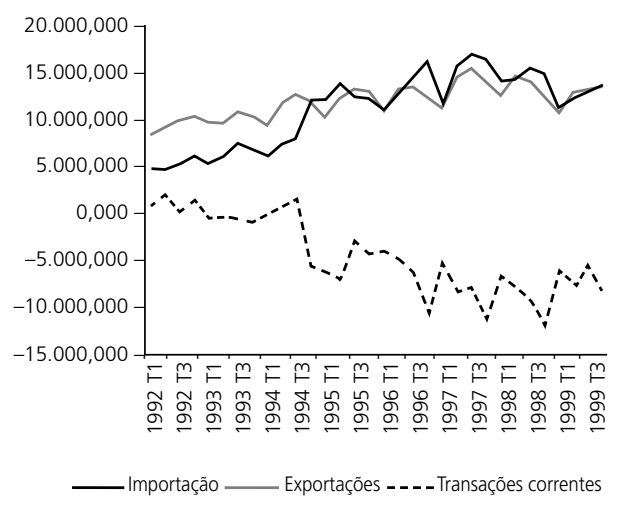

Fonte: Boletim do Banco Central do Brasil.

sumo presente e futuro de importações. Mas esses fatores perderiam em grande medida o poder explicativo caso não houvesse a substancial mudança na taxa de câmbio. A estabilidade cambial, e mesmo a supervalorização cambial, também agiu no sentido de acelerar as importações e de gerar déficits comerciais.

Relacionando-se os saldos comerciais com a conta de transações correntes, percebe-se que esta última, antes do Plano Real, manteve um comportamento oscilante, porém próximo ao equilíbrio. Após a implementação do Plano, em particular no último trimestre de 1994, a conta de transações correntes passa a acumular sucessivos déficits - que permanecem ao longo de toda a ancoragem cambial —, coincidindo, dessa maneira, com o momento em que a balança comercial se torna deficitária. Conclui-se que os déficits gerados na balança comercial apoiaram a deterioração da conta de transações correntes. Isso pode ser verificado no gráfico 2. Para reforçar essa conclusão, o coeficiente de correlação entre o saldo da balança comercial e o da conta de transações correntes, entre julho de 1994 e janeiro de 1999, foi de 0,81 . Com base nessa discussão pode-se concluir que, ao longo do Plano Real, a supervalorização cambial, associada ao aumento da absorção doméstica, permitiu a deterioração de dois importantes fundamentos: a balança comercial e, dessa forma, a conta corrente. ${ }^{13}$

O próximo passo é identificar as principais fontes de financiamento dos déficits em conta de transações correntes. Como sabemos, a identidade bá- 


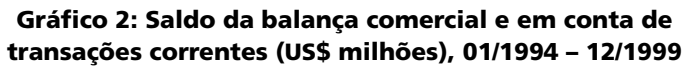
transações correntes (US\$ milhões), 01/1994 - 12/1999

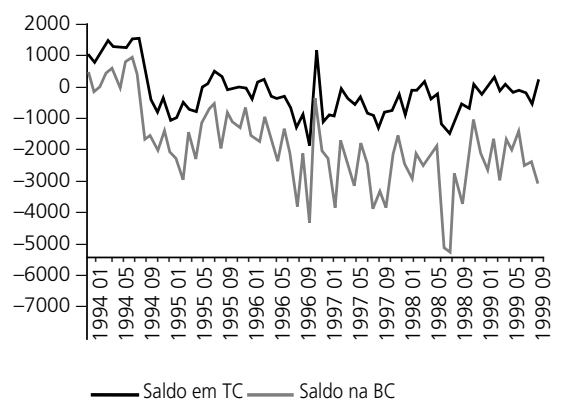

Fonte: Boletim do Banco Central do Brasil.

sica das contas nacionais para uma economia aberta e com governo mostra que, caso a economia experimente desequilíbrios em sua conta de transações correntes, eles deverão ser financiados via três formas de poupança: poupança privada e poupança pública, que, conjuntamente, compõem a poupança interna, e poupança externa. Como a poupança privada é insuficiente e a poupança pública brasileira é historicamente deficitária, resta a poupança externa. Por conseqüência, a forma de o país financiar seus desequilíbrios em conta corrente foi via atração de capitais externos. Além disso, a atração de capitais externos também foi utilizada para gerar um volume considerável de reservas internacionais necessário à consecução do plano de estabilização. A tabela 4 discrimina a entrada de capitais no Brasil durante o Plano Real.

Analisando-se as fontes de financiamento externo, não se pode desconsiderar o papel dos investimentos diretos estrangeiros em decorrência de sua estabilidade. Os dados, no entanto, também apontam para uma considerável participação dos investimentos em carteira. Os investimentos em carteira representam as aquisições feitas por não residentes de títulos de renda variável (ações) e de renda fixa (títulos de dívida) de emissão brasileira [Brasil, Banco Central do Brasil (2001)]. Tais capitais são, em sua maioria, de curto prazo e voláteis, o que implica uso de fonte não estável de financiamento. Ademais, a captação desses recursos demandou a construção de um considerável diferencial de taxa de juros cujo impacto fiscal não foi desprezível e será objeto da próxima seção. 
Tabela 4: Saldo da conta financeira, contas principais (US\$ milhões), 1994-1998

\begin{tabular}{lccccc}
\hline Período & $\begin{array}{c}\text { Saldo da conta } \\
\text { financeira }\end{array}$ & $\begin{array}{c}\text { Investimentos } \\
\text { diretos }\end{array}$ & Derivativos & $\begin{array}{c}\text { Outros } \\
\text { investimentos }\end{array}$ & $\begin{array}{c}\text { Investimentos em } \\
\text { carteira }\end{array}$ \\
\hline 1994 & $8.518,276$ & $1.460,000$ & $-27,424$ & $-43.556,500$ & $50.642,200$ \\
\hline 1995 & $28.743,766$ & $3.309,484$ & 17,464 & $16.200,031$ & $9.216,787$ \\
\hline 1996 & $33.514,242$ & $11.260,751$ & $-38,337$ & 672,960 & $21.618,868$ \\
\hline 1997 & $25.407,742$ & $17.877,370$ & $-252,623$ & $-4.832,577$ & $12.615,571$ \\
\hline 1998 & $29.381,226$ & $26.001,597$ & $-459,845$ & $-14.285,499$ & $18.124,973$ \\
\hline Fonte: Boletim do Banco Central do Brasil.
\end{tabular}

Nota: O saldo da conta financeira é igual ao somatório dos investimentos diretos estrangeiros, derivativos, outros investimentos e investimentos em carteira.

\section{FUNDAMENTOS FISCAIS}

Essencial à análise do caso brasileiro na década de 1990 é determinar o comportamento das contas fiscais no período. A âncora cambial, como já discutido, gera a necessidade de se acumularem reservas internacionais para dar credibilidade ao plano e, por outro lado, tende a desestabilizar as contas externas na figura de déficits em transações correntes. Em conseqüência, torna-se necessária a atração de capitais estrangeiros.

Inicia-se, dessa maneira, um ciclo de endividamento. A captação de recursos em algumas categorias já se configura em endividamento externo. $\mathrm{Na}$ verdade, a dívida externa pública até apresentou um comportamento declinante ao longo do Plano Real, só voltando a crescer após a crise russa. A dívida externa total, por outro lado, mostrou comportamento ascendente. Comparando-se os cinco anos antes do Plano Real, compreendendo 1989 a 1993, com os dados do Plano Real de 1994 a 1998, percebe-se que no período anterior o crescimento da dívida externa foi de cerca de $28 \%$, enquanto no período do Plano o crescimento foi em torno de $66 \%{ }^{14}$

Na outra ponta, a captação de recursos externos, em parte, tendia a pressionar os agregados monetários, o que, por sua vez, poderia gerar instabilidades sobre os níveis de preços. A redução da liquidez da economia era necessária. Isso era feito por meio de operações de mercado aberto, que, inevitavelmente, conduziam ao aumento da dívida interna. Surgia então um círculo vicioso: recursos externos eram captados e, via enxugamento da liquidez, transformados em dívida interna. A cada novo período tornava-se necessária nova captação de recursos externos, o que, conseqüentemente, propiciava nova ampliação da dívida interna. 
O gráfico 3 demonstra, em especial, o vultoso crescimento da dívida interna. A captação de recursos externos, como assinalado, se transformava em dívida interna. Deve-se considerar que esse crescimento da dívida pública interna, decorrente da colocação de títulos para neutralizar os efeitos monetários do ingresso de recursos externos, não afetava diretamente a dívida líquida do setor público. ${ }^{15} \mathrm{O}$ problema residia, como será visto a seguir, na conta juros.

À medida que a dívida interna tinha seu montante ampliado, eram requeridas maiores taxas de juros para remunerá-la, ou, no mínimo, implicava a não-possibilidade de uma maior redução. Como resultado, foram aumentados significativamente os serviços dessa dívida (ampliação da conta juros), o que, por sua vez, pressionou o déficit nominal. Por fim, para honrar seus compromissos diante da existência de uma necessidade de financiamento do setor público nominal positiva, o governo incorreu em novas emissões de papéis da dívida pública. Além disso, todos esses efeitos foram ampliados por três ataques especulativos de proporções globais, que, via canal monetário, ou seja, via elevação da taxa de juros para manter o padrão cambial à época vigente, deterioraram ainda mais as contas fiscais brasileiras. Para fechar o raciocínio inicial, gerou-se, de fato, um círculo vicioso de deterioração da contas públicas. ${ }^{16}$ Foi, de fato, construída uma armadilha entre captação de recursos externos, aumento da dívida interna e geração de déficits nominais, que, inevitavelmente, causaria uma crise no futuro. Era

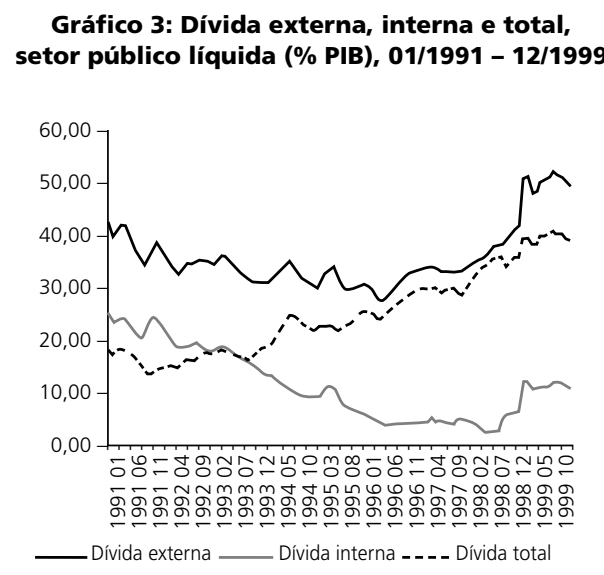

Fonte: Boletim do Banco Central do Brasil. 
impossível manter indefinidamente o padrão cambial vigente durante o Plano Real conjuntamente com o forte crescimento da conta juros. Poderia ocorrer uma crise monetária e/ou uma moratória. Aconteceu a primeira. Para ilustrar essa situação, na tabela 5 é reproduzida a necessidade de financiamento do setor público nominal, mas também a necessidade primária, que será discutida em seguida.

O déficit nominal, ou o operacional para efeito de comparabilidade com o período pré-estabilização monetária, demonstrou o comportamento anteriormente citado de ascendência. Isso reflete principalmente o aumento das despesas com a conta juros. Mais interessante, no entanto, é avaliar o resultado primário. O governo possui poucos graus de liberdade para atuar diretamente sobre as despesas com juros. Por outro lado, no que tange às contas primárias, a capacidade de ação é maior. Portanto, era de esperar uma atuação mais decisiva sobre esse componente, principalmente por causa do plano de estabilização vigente àquela época.

No início do Plano Real, com a implantação do Fundo Social de Emergência, que, na verdade, correspondia à desvinculação de receitas da União, houve, de fato, uma tentativa de ajuste das contas públicas com o superávit primário atingindo 5,64\% do PIB em 1994. Logo em seguida, contudo, ocorreu o afrouxamento do controle fiscal, que resultou, inclusive, na geração de déficits primários nos anos 1996 e 1997. Possivelmente essa foi a maior falha na condução da política econômica durante o plano de estabilização. A não

Tabela 5: Necessidade de financiamento do setor público total: nominal, operacional e primária (\%PIB), 1990-1999

\begin{tabular}{lccc}
\hline Período & Nominal & Operacional & Primário \\
\hline 1990 & 30,15 & $-1,32$ & $-4,69$ \\
\hline 1991 & 26,75 & 0,19 & $-2,71$ \\
\hline 1992 & 45,75 & 1,74 & $-1,58$ \\
\hline 1993 & 64,83 & 0,80 & $-2,18$ \\
\hline 1994 & 26,97 & $-1,57$ & $-5,64$ \\
\hline 1995 & 7,28 & 5,00 & $-0,26$ \\
\hline 1996 & 5,87 & 3,40 & 0,10 \\
\hline 1997 & 6,11 & 4,31 & 0,96 \\
\hline 1998 & 7,93 & 7,40 & $-0,02$ \\
\hline
\end{tabular}

Fonte: Boletim do Banco Central do Brasil.

Notas: (+) deficit e (-) superavit. 
efetiva realização de um ajuste fiscal acabou por impedir a redução das taxas de juros, propiciando, dessa maneira, o crescimento da dívida pública. Não menos grave, o não-equacionamento dos desequilíbrios fiscais impedia um deslizamento mais acelerado da taxa de câmbio, o que, por sua vez, contribuía para a contínua piora das contas externas.

Uma possível forma de analisar a atuação do governo no que tange ao desenvolvimento de sua política fiscal é avaliar sua restrição orçamentária intertemporal. Hamilton e Flavin (1986) e Trehan e Walsh (1991), ao analisarem a economia norte-americana, propuseram dois testes simples para verificar a solvência do governo. Em seguida, serão resumidos esses dois testes e aplicados para o caso brasileiro no período de 1994 a 1998. O objetivo é verificar se durante o Plano Real houve o equilíbrio orçamentário intertemporal. Não se pretende, no entanto, realizar um teste extensivo, mas tão-somente mostrar indícios das condições fiscais do país no período.

O teste proposto por Hamilton e Flavin consiste na realização de um teste de raiz unitária, utilizando-se o teste de Dickey-Fuller, sobre duas variáveis representativas das contas fiscais: o déficit primário e o estoque da dívida pública. Caso essas variáveis mostrem-se estacionárias, pode-se considerar que a restrição orçamentária intertemporal do governo está sendo respeitada. ${ }^{17}$ Trehan e Walsh (1991), por sua vez, partindo do pressuposto de que a taxa de juros real esperada é variável e estritamente positiva, defendem que a restrição orçamentária intertemporal do governo será respeitada caso o déficit nominal seja estacionário. ${ }^{18}$ Os autores realizam essa observação afirmando que a "estacionariedade do déficit nominal é suficiente para assegurar o equilíbrio orçamentário intertemporal, desde que a taxa de juros real esperada seja positiva" [Trehan e Walsh (1991, p. 215)]. Com base nessa discussão, são mostrados os resultados para a economia brasileira. ${ }^{19}$

Os resultados demonstram a não-estacionariedade da dívida pública, do déficit operacional e do déficit primário - esta última variável apenas no teste de Phillips-Perron. De acordo com esses resultados, a restrição orçamentária intertemporal do governo não estava sendo respeitada no período do Plano Real. Essta afirmação, no entanto, tem de ser analisada com alguma ressalva. Os testes propostos por Hamilton e Flavin e Trehan e Walsh demonstram as condições para a solvência intertemporal do gover- 
no, mas isso não necessariamente equivale a dizer que se essas condições não forem satisfeitas a restrição intertemporal não estará sendo respeitada. Efetivamente, o que se pode afirmar é que os dois testes realizados não puderam confirmar a solvência das contas fiscais brasileiras. Porém, esse pode ser considerado um importante indício da deterioração fiscal do país no período.

A avaliação do lado fiscal demonstrou que os fundamentos relativos à dívida e ao déficit público sofreram forte deterioração durante o Plano Real. A situação desses fundamentos tornava-se ainda pior a cada novo ataque especulativo que acometia a economia brasileira. Como conclusão, pode-se inferir que tais variáveis contribuíram para as pressões cambiais sofridas no período e, mais decisivamente, para a crise cambial de janeiro de 1999.

\section{FUNDAMENTOS MONETÁRIOS}

Um número considerável de artigos sinaliza para o crescimento descontrolado dos agregados monetários ou do crédito doméstico como uma das principais fontes causadoras de crises cambiais. Torna-se, então, necessário verificar o comportamento dessas variáveis para tentar estabelecer a suposta relação entre descontrole monetário e desequilíbrios cambiais.

No início do Plano Real, em decorrência da repentina e vigorosa queda das taxas de inflação, houve um natural aumento da demanda por moeda. A atitude do governo nesse primeiro momento foi permitir a remonetiza-

Tabela 6: Testes de raiz unitária, Dickey-Fuller aumentado e Phillips-Perron²0

\begin{tabular}{lccccccc}
\hline & $\begin{array}{c}\text { Componentes } \\
\text { determinísticos }\end{array}$ & ADF & Lag & $\begin{array}{c}\text { Resultado } \\
\text { ADF }\end{array}$ & PP & Lag & $\begin{array}{c}\text { Resultado } \\
\text { PP }\end{array}$ \\
\hline $\begin{array}{l}\text { Dívida } \\
\text { pública }\end{array}$ & cte e tend. & $-0,903^{*}$ & 3 & não estacionário & $-0,730^{*}$ & 1 & $\begin{array}{c}\text { não } \\
\text { estacionário }\end{array}$ \\
\hline $\begin{array}{l}\text { Déficit } \\
\text { operacional }\end{array}$ & cte e tend. & $-3,411^{* *}$ & 12 & não estacionário & $-2,193^{*}$ & 2 & $\begin{array}{c}\text { não } \\
\text { estacionário }\end{array}$ \\
\hline $\begin{array}{l}\text { Déficit } \\
\text { primário }\end{array}$ & - & $-2,547$ & 12 & estacionário & $-1,412^{* *}$ & 4 & não \\
estacionário
\end{tabular}

Fonte: Elaborada pelos autores a partir de dados do Boletim do Banco Central do Brasil.

Notas: (1) A dívida pública corresponde à dívida pública líquida do setor público total como proporção do PIB. (2) O déficit primário corresponde às necessidades de financiamento primário do setor público (acumulado 12 meses como proporção do PIB). (3) O déficit operacional corresponde às necessidades de financiamento operacional do setor público (acumulada 12 meses como proporção do PIB). (4) * significa que a hipótese nula de nãoestacionariedade foi aceita no nível de significância de $1 \%$. (5) ** significa que a hipótese nula de nãoestacionariedade foi aceita no nível de significância de 5\%. (6) O lag, no teste de Phillips-Perron, corresponde ao bandwidth (Newey-West). 
ção da economia, propiciando o aumento da oferta de moeda. O forte aumento da demanda, ao provocar bolhas de consumo e a deterioração das contas externas, fez com que as autoridades monetárias passassem a realizar políticas monetárias acentuadamente contracionistas por meio da contração do crédito e, principalmente, por meio da elevação das taxas de juros.

A tônica da política monetária foi a construção de consideráveis diferenciais de taxas de juros. Os objetivos dessa política eram reduzir a demanda, e assim a absorção externa, e propiciar a entrada de capitais externos necessários à consecução do Plano Real, e em especial da âncora cambial. Tal política, no entanto, demandou a realização de contínuas políticas de esterilização, o que, associado à elevação da conta juros, impactou sobremaneira as contas fiscais do país. Essa condição pode ser vista na evolução da base monetária ampliada, que, além de conter a base monetária restrita [base monetária e meios de pagamento (M1)], contempla também os principais passivos do Banco Central e do Tesouro Nacional (depósitos compulsórios e títulos federais).

No gráfico 4 é mostrado o comportamento da base monetária ampliada, que foi claramente crescente ao longo do Plano Real. Isso se deve, como apontado, à acumulação de dívidas por parte do Banco Central e do Tesouro Nacional derivadas das operações de esterilização. Além disso, a partir de certo ponto de deterioração das contas fiscais, a acumulação de dívidas também se deu em decorrência da necessidade de financiar os serviços de dívidas preexistentes e até mesmo de déficits primários, como visto na subseção anterior.

O elemento mais importante da política monetária durante o Plano Real não era o possível desequilíbrio nos agregados monetários. A contribuição da política monetária para a deterioração dos fundamentos macroeconômicos do país se deu por meio da construção de consideráveis diferenciais de taxas de juros, e assim da conta fiscal de juros derivada, e por meio da esterilização dos influxos de capitais. Isso pode ser visto no crescimento da base monetária ampliada, que sinaliza para o aumento do endividamento do país. Em conclusão, pode-se afirmar que a condução da política monetária contribuiu para agravar os desequilíbrios fiscais. Pastore e Pinotti (1999a) e Andrade, Silva e Carneiro (2000) também sugerem essa mesma análise.

Outra importante variável monetária é o crédito doméstico. Um grande número de artigos de crises cambiais originadas na deterioração dos funda- 


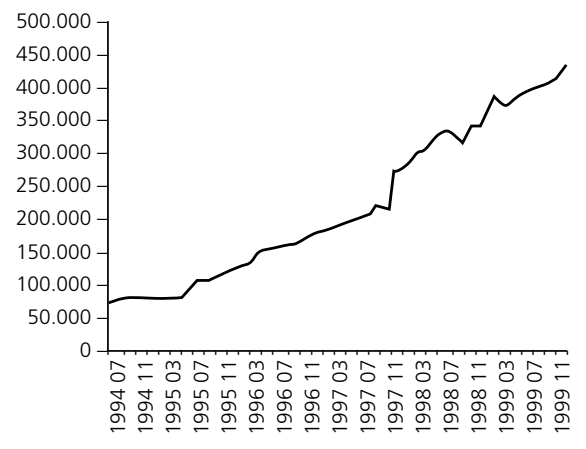

Fonte: Boletim do Banco Central do Brasil.

mentos macroeconômicos demonstra que a expansão do crédito doméstico é uma das principais fontes de ataques especulativos [Krugman (1979), Flood e Garber (1984), Obstfeld (1984), Flood, Garber e Kramer (1996), entre outros].

Em economias em que a taxa de câmbio é fixa ou administrada, a oferta de moeda torna-se endógena, e no caso da taxa administrada há ainda algum espaço para a discricionariedade na condução da política monetária. A atuação das autoridades monetárias passa a se dar sobre o crédito doméstico por meio de operações de redesconto e, principalmente, operações de mercado aberto. Dito isso, torna-se relevante avaliar o comportamento do crédito doméstico no Brasil durante o Plano Real. Caso essa variável tenha tido um comportamento notadamente ascendente, pode-se inferir que ela contribuiu para as pressões sofridas pela taxa de câmbio. Primeiramente, analisar-se-á o conceito mais simples de crédito doméstico que é o de crédito doméstico líquido, obtido a partir da diferença entre o M1 (papelmoeda em poder do público e depósitos à vista) e as reservas internacionais líquidas.

De fato, no âmbito dos acordos do Brasil com o Fundo Monetário Internacional (FMI) estabelecidos a partir de 1998 após a ocorrência da crise da Rússia, o crédito doméstico líquido foi definido como a diferença entre a base monetária e as reservas internacionais líquidas no Banco Central do Brasil (BCB). Mas, seguindo Andrade, Silva e Carneiro (2000), optou-se por utilizar o conceito de crédito doméstico líquido definido como a diferença 
entre o M1 e as reservas internacionais líquidas. Ademais, como será visto na análise adiante, é importante a distinção entre base monetária e crédito doméstico líquido (M1 menos reservas internacionais líquidas).

Com base no gráfico 5, que replica em grande medida a figura 5 de Andrade, Silva e Carneiro (2000, p. 240), percebe-se que o comportamento do crédito doméstico líquido mostra-se como o inverso das reservas internacionais, o que reflete o uso intensivo pelas autoridades monetárias de operações de esterilização. Contudo, como colocam Flood e Garber (1984) e Flood, Garber e Kramer (1996), o comportamento padrão prévio a um ataque especulativo, ou mesmo a um colapso cambial, demonstra a ascensão do crédito doméstico e a concomitante redução das reservas internacionais, além da constância da base monetária. Após o ataque, o crédito doméstico e as reservas mantêm o comportamento anteriormente citado, mas há uma queda discreta da base monetária. Os resultados para o Brasil, no entanto, contradizem essas condições. Primeiramente, a base monetária, após os períodos de ataque especulativo, não sofreu uma queda discreta, o que demonstra que em parte os efeitos da queda das reservas internacionais foram esterilizados pela expansão do crédito. Porém, a expansão do crédito ocorrida pode ser considerada limitada, dado que em nenhum momento as reservas internacionais tornaram-se menores que o crédito doméstico líquido, como sugerem os modelos padrões.

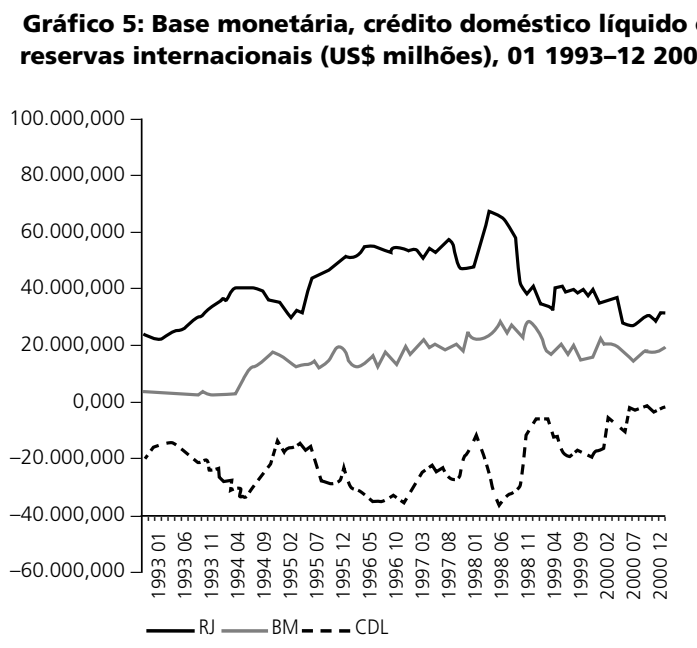

Fonte: Elaborada pelos autores a partir de dados do Boletim do Banco Central do Brasil. 
Também se pode avaliar o comportamento do crédito doméstico a partir dos dados das operações de crédito do sistema financeiro. A variável assinalada é importante porque dimensiona a saúde do sistema financeiro de uma economia. A esse respeito é válido destacar que uma das fontes da crise asiática foi a concessão excessiva de empréstimos para projetos duvidosos. Conseqüentemente, um crescimento acelerado na concessão de empréstimos, sem as devidas supervisão e regulação bancária, pode resultar em crises financeiras que se alastram para crises cambiais. O crescimento descontrolado das operações de crédito pode, então, ser considerado como mais um representante da deterioração dos fundamentos macroeconômicos de um país e, portanto, um candidato a proporcionar ataques especulativos. São as chamadas crises gêmeas. Torna-se, então, também necessário verificar a evolução das operações de crédito no Brasil.

Os dados das operações de crédito do sistema financeiro (total) no Brasil (como proporção do PIB) demonstram que houve uma evolução das operações de crédito no período anterior ao Plano Real, que, no entanto, após a sua vigência, passaram a ser declinantes. Logo em seguida, tornaram-se estáveis em um patamar de 30 a 35\% do PIB. Em conseqüência, essa variável, a princípio, não demonstrou um comportamento que poderia afetar negativamente a taxa de câmbio.

Outro elemento a ser analisado é a criação de crédito pelo setor público. A expansão desse tipo de operação de crédito ocorre normalmente como um meio de as autoridades monetárias financiarem déficits orçamentários, tornando-se, dessa maneira, uma importante fonte geradora de desequilíbrios cambiais. Entre julho de 1994 e dezembro de 1998, essa não parece ser uma característica marcante da política econômica brasileira, porque, como visto, o financiamento do setor público se deu prioritariamente via endividamento interno. O crédito doméstico do setor público (como proporção do PIB) nos quatro anos e meio do Plano Real, de acordo com as estimativas feitas a partir de dados do Boletim do Banco Central do Brasil, mostrou um comportamento semelhante às operações de crédito totais da economia. Houve, inicialmente, nítida tendência de queda dessa variável, que, em seguida, a partir de meados de 1995, se manteve relativamente estável, permanecendo entre 5 e $7 \%$ do PIB. Deve-se destacar também que após a crise asiática, em fins de 1997, houve uma nova queda das operações de crédito de setor público, o que refletia os ajustes feitos na economia após essa crise. ${ }^{20}$ 
Com base nas discussões apresentadas, percebe-se que a evolução dos agregados monetários e das diversas variações do crédito doméstico não demonstrou indícios de um excessivo crescimento. Assim, não se pode precisar a contribuição dessas variáveis para as pressões sofridas pela taxa de câmbio durante o Plano Real. As análises da literatura econômica brasileira inclusive não destacam o papel dessas variáveis em desestabilizar o mercado cambial. Dessa maneira, sugere-se que o estudo do inter-relacionamento entre os agregados monetários e o crédito doméstico com a taxa de câmbio deva ser aprofundado. Por outro lado, é inequívoca a contribuição da política de elevadas taxas de juros na deterioração dos fundamentos econômicos do país, e em especial das contas fiscais.

\section{OS EFEITOS DO CICLO ELEITORAL SOBRE OS FUNDAMENTOS ECONÔMICOS BRASILEIROS}

Nesta seção pretende-se fazer uma digressão acerca dos efeitos do ciclo eleitoral sobre algumas importantes variáveis macroeconômicas. Particularmente, objetiva-se demonstrar se a atuação do governo na condução da política econômica, em 1998, foi pautada pela busca do equilíbrio macroeconômico ou se foi desenvolvida de acordo com as necessidades eleitorais do período. Não é objetivo, contudo, descrever as teorias relativas aos ciclos eleitorais, mas tão-somente avaliar a tendência de algumas variáveis em um ano de eleições. Pretende-se, então, determinar se os fundamentos anteriormente descritos tornaram-se ainda mais deteriorados como conseqüência de interesses eleitorais.

O Brasil, durante sua experiência de taxas de câmbio administradas, sofreu diversos ataques especulativos. No entanto, o ataque que fez com que o regime cambial finalmente sucumbisse ocorreu logo após as eleições presidenciais. Dentro desse contexto, pode-se estabelecer uma correlação entre as eleições, o aprofundamento dos desequilíbrios macroeconômicos e, finalmente, a possibilidade da crise cambial. Essa análise parte do princípio de que em um ano eleitoral o grupo que ocupa o poder, e que possui em sua função utilidade a manutenção do poder, deve adotar políticas que produzam baixas taxas inflacionárias concomitantemente com algum nível razoável de crescimento econômico às expensas de seus efeitos futuros. Para obter 
esse resultado, a taxa de câmbio, funcionando como uma âncora nominal, cumpre importante papel.

Calvo e Végh $(1993,1998)$ e Rebelo e Végh (1995), entre outros, destacam que o estabelecimento de uma âncora nominal a partir da taxa de câmbio permite que, como já abordado, a inflação interna convirja para os níveis da inflação mundial, pelo menos no que tange aos bens comercializáveis, além de reverter expectativas inflacionárias. Conseqüentemente, controlamse os preços. O outro ponto importante é que a âncora cambial, diferentemente da âncora monetária, não traz tantos prejuízos em termos da evolução do produto. Daí surge a defesa da âncora cambial como instrumento de política econômica com objetivos políticos.

A âncora cambial, no entanto, traz consigo o problema da supervalorização da taxa de câmbio e todas as suas conseqüências derivadas. Há a deterioração dos saldos comerciais, que culmina em desequilíbrios das contas externas. Tais desequilíbrios, em geral, são financiados por capitais voláteis remunerados a grandes diferenciais de taxas de juros, que, por sua vez, acabam por ampliar os desequilíbrios fiscais. Esse cenário, diante de um ambiente de reformas institucionais incompletas, torna-se extremamente propenso à deflagração de uma possível crise do balanço de pagamentos e à reversão de muitos dos ganhos obtidos com a estabilidade econômica.

O caso brasileiro nos anos 1990 se adequou à discussão apresentada no parágrafo anterior. A âncora cambial logrou efeito em conseguir a estabilidade dos níveis de preços. Houve algum impacto negativo em termos de emprego e crescimento econômico, porém provavelmente inferior àqueles que seriam obtidos com uma âncora nominal. O restante, desequilíbrios externos e fiscais e a falta de uma maior agenda de reformas institucionais, completa o cenário. Diante desse quadro, inevitavelmente em algum momento futuro a âncora cambial seria rompida.

Cabe, no entanto, ressaltar que um maior deslizamento da taxa de câmbio e uma maior disciplina fiscal poderiam evitar a crise cambial e suas conseqüências. Porém, as medidas derivadas em grande parte também poderiam se mostrar negativas do ponto de vista eleitoral. A opção então foi a manutenção da rigidez no controle da taxa de câmbio. Houve algum realinhamento cambial, porém não suficiente para reverter a supervalorização construída junto com o real. Para confirmar essa afirmação, basta destacar 
que, nos três meses que antecederam as eleições, entre julho e setembro de 1998, a supervalorização cambial, calculada a partir do IPC, encontrava-se entre 20 e 25\% (apesar da crise russa de agosto de 1998). Dessa maneira, pode-se pelo menos inferir que houve um retardamento no realinhamento da taxa de câmbio real que coincide com o período eleitoral.

Outras variáveis devem ser observadas com intuito de estabelecer a relação entre a condução da política econômica e os objetivos eleitorais. Candidatos naturais ao uso político da economia são o crédito doméstico relativo ao setor público e os resultados fiscais, particularmente os resultados primários, em que o governo possui maior grau de liberdade para atuar. No que tange às operações de crédito do setor público, medidas como proporção do PIB ou como proporção do crédito total da economia, não se confirma o uso dessa variável com objetivos eleitorais. Já no que se refere às contas fiscais, por outro lado, os resultados são alterados. Focando a análise na necessidade de financiamento público primária, verifica-se que no período prévio às eleições de outubro de 1998 foram gerados os maiores déficits fiscais da era do real. A importância de tais resultados (negativos) é ampliada quando se lembra que, após a crise da Ásia, em fins de 1997, o governo lançou um pacote de medidas de ajuste fiscal que, a partir desses resultados, se pode concluir que não foram seguidas. Portanto, nesse momento a economia brasileira mostrava-se com fundamentos deteriorados e, além disso, com a credibilidade das autoridades governamentais comprometida. O gráfico 6 permite a visualização dessas análises.

Ainda em relação às contas fiscais, porém enfocando não as eleições gerais de 1998, mas a eleição municipal de 1996, também é percebido o advento de um ciclo eleitoral. Mesmo que os dados sejam agregados, englobando, inclusive, a União e os Estados, não se pode desconsiderar o papel desses entes federativos nos pleitos municipais. Colocando em termos mais explícitos, o Governo Federal e os Estados, na figura de seus representantes, têm interesses nas eleições municipais, buscando influenciá-las. Voltando para os dados, até março de 1996 foram produzidos superávits fiscais primários; a partir do mês seguinte, em abril, passou-se a realizar sucessivos déficits, que, a partir de 1997, foram estancados. Conseqüentemente, pode-se inferir que há indícios de que a política fiscal também foi utilizada como instrumento de apoio durante as eleições de 1996. 


\section{Gráfico 6: Necessidade de financiamento do setor público \\ primária como proporção do PIB (\%), 01 1994-12 1999}

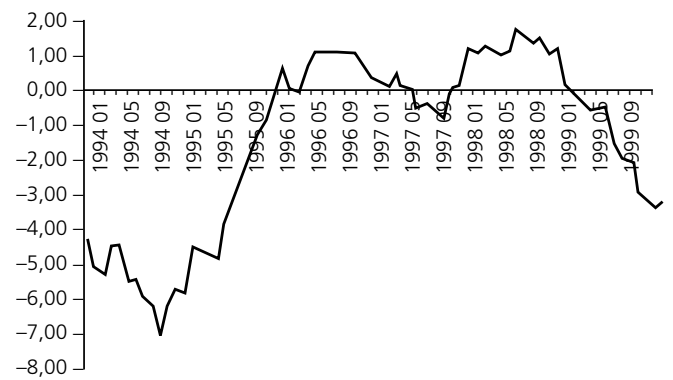

Fonte: Boletim do Banco Central do Brasil. Disponível em: <http://www.ipeadata.gov.br> Notas: Valores maiores representam um maior déficit primário.

Em conclusão, as análises apresentadas permitem mostrar indícios, pelo menos no que tange à condução da política cambial e fiscal, de que efetivamente ocorreu um ciclo eleitoral no ano 1998, o que, conseqüentemente, possibilitou um aprofundamento da deterioração dos fundamentos macroeconômicos do país. Dessa maneira, foi ampliada a probabilidade de ocorrência de uma crise cambial, como de fato veio a acontecer em janeiro de 1999.

\section{CONCLUSÕES}

Este artigo cumpriu três objetivos. Primeiro, foi realizada uma resenha acerca da literatura que analisa a experiência de taxas de câmbio administradas ocorrida nos anos 1990, em especial sendo verificados os principais fatores causadores das pressões cambiais e ataques especulativos sofridos pela moeda brasileira naquele período. Em seguida, dado que o principal fator causador das instabilidades cambiais foi especificado como a deterioração dos fundamentos econômicos, passou-se ao desenvolvimento de uma análise descritiva das principais variáveis macroeconômicas do país. Por último, verificou-se a condição dos citados fundamentos especificamente no ano 1998. Buscou-se, dessa forma, determinar a ocorrência de um ciclo eleitoral no período.

Em relação ao primeiro objetivo do trabalho não são necessários comentários adicionais, bastando reafirmar que grande parte da literatura sobre os 
desequilíbrios cambiais vividos pelo Brasil durante os anos 1990 sinaliza para a deterioração dos fundamentos econômicos, em especial dos fundamentos relativos às contas externas e às contas fiscais. Isso posto, passou-se, nas três seções seguintes, a verificar qual foi o real comprometimento dos fundamentos brasileiros. Especificamente, foram analisados os fundamentos externos, fiscais e monetários.

A avaliação do setor externo mostrou que a construção da estabilidade econômica a partir de uma âncora cambial conduziu à supervalorização da taxa de câmbio. Para chegar a esse resultado, foram construídas medidas de supervalorização cambial a partir do desvio da taxa de câmbio nominal da regra de poder de paridade de compra. Como resultado dos desequilíbrios no câmbio real, entre outros fatores, a conta de transações correntes tornouse deficitária. Esse problema teve sua gravidade ampliada, na medida em que o governo financiava tais déficits por meio da atração de capitais externos em geral voláteis e remunerados com altas taxas de juros. Colocando de outra maneira, o financiamento dos desequilíbrios em conta de transações correntes era instável e oneroso.

Os problemas nas contas externas, por sua vez, estão estreitamente relacionados com a deterioração das contas fiscais. Os capitais externos, em sua maioria, eram esterilizados via operações de mercado aberto. Em conseqüência, o endividamento interno foi crescente e trouxe consigo a realização de contínuos e crescentes déficits operacionais (e nominais). Como um agravante tem-se que a cada novo ataque especulativo sofrido pela economia brasileira um novo choque de taxas de juros era realizado e as contas fiscais tornavam-se ainda mais desequilibradas em decorrência da elevação da conta juros. As análises realizadas também mostraram que não menos grave em relação ao setor fiscal foi a não-realização de um efetivo ajuste nas contas primárias. Tal fato acabou por minar tanto os fundamentos do país quanto a credibilidade dos agentes na política econômica governamental. Sendo assim, tem-se que os fundamentos eram ruins e as autoridades governamentais não sinalizavam para políticas que melhorassem esses fundamentos.

Já no que se refere à política monetária, o mais grave foi a utilização desse instrumento para a manutenção da âncora cambial, o que, via elevação das taxas de juros e elevação dos serviços da dívida interna, acabou por 
comprometer as contas fiscais brasileiras. Em outros termos, ficou demonstrado que a manutenção da âncora cambial diante de sucessivos ataques especulativos por meio de uma política monetária altamente contracionista contribuiu sobremaneira para a piora dos fundamentos brasileiros, e inclusive impediu um maior deslizamento da taxa de câmbio. Em conclusão, o inter-relacionamento entre a estreita administração cambial, forte contração monetária e política fiscal frouxa formou os ingredientes para uma inescapável crise que veio a ocorrer em janeiro de 1999. Existia, na verdade, uma endogenia entre a rígida administração da taxa de câmbio, deterioração dos fundamentos econômicos e desequilíbrios cambiais.

Por fim, tratou-se dos efeitos da eleição de 1998 sobre os fundamentos e, conseqüentemente, sobre os desequilíbrios cambiais. Ficou evidenciado que, de fato, ocorreu um ciclo eleitoral no período com a postergação na correção da defasagem cambial e a ampliação dos desequilíbrios fiscais, inclusive de desequilíbrios primários. Enfim, a reticência em realizar em tempo hábil as reformas necessárias à condução da política econômica, aparentemente, mas não exclusivamente, com objetivos eleitorais, dá-nos indícios de que essa atitude também contribuiu para a crise cambial de janeiro de 1999.

\section{NOTAS}

1. São os chamados modelos de primeira geração de crises cambiais. Trabalhos iniciais a respeito dessa literatura podem ser vistos em Krugman (1979), Flood e Garber (1984) e Obstfeld (1984).

2. São os modelos de segunda geração de crises cambiais. Para a descrição desta teoria, ver Obstfeld (1986, 1994).

3. A teoria do efeito contágio é subdividida em diversos modelos. Uma importante resenha desses pode ser vista em Forbes e Rigobon (2001).

4. O teste realizado por Arbex e Fontes aproxima-se da análise dos modelos de segunda geração de crises cambiais. Nesses modelos, também denominados modelos de profecias auto-realizáveis, as crises ocorrem por causa da perda de credibilidade dos agentes nas políticas governamentais. A perda de credibilidade, por seu turno, decorre da diminuição do apoio político ao governo, que, em geral, é oriunda do aumento das taxas de desemprego e da redução do crescimento econômico. O governo, para tentar recuperar seu prestígio junto à população, pode se sentir tentado a desenvolver políticas que conduzam à desvalorização cambial, porém os agentes se antecipam às medidas e provocam a crise cambial. Pode-se, finalmente, citar que o evento mais relevante de crise dita autorealizável acometeu o Sistema Monetário Europeu em 1992.

5. A esse respeito, ver a nota de rodapé número 2 de Pastore e Pinotti (1999). 
6. O referido artigo possui informações que se estendem até fins de 1998. Portanto, ele é anterior à crise cambial de janeiro de 1999. Porém, Schwartsman, na página 17, ao analisar a evolução da economia brasileira, fez a seguinte afirmação: "o ajuste fiscal se torna condição absolutamente necessária à preservação da política monetária e, portanto, da política cambial”. A afirmação, de fato, é correta, porém os acontecimentos futuros demonstraram que o timing para o ajustamento fiscal já havia passado.

7. Como um atenuante para tal colocação pode-se considerar que o governo não tinha mais opções de política econômica quando da ocorrência do ataque especulativo, que, no caso, foi em janeiro de 1999. Porém, nos momentos anteriores a esse ataque, não se pode descartar a existência de ingredientes relativos aos modelos de segunda geração de crises cambiais, em especial no período logo anterior às eleições de 1998.

8. Conforme discutido em Menezes, Moreira e Souza (2005), a zona de credibilidade nula é uma situação em que o estoque da dívida externa (a variável considerada como fundamento para a economia) é tão elevado que as autoridades monetárias abandonarão a administração cambial independentemente das expectativas dos agentes. Conseqüentemente, a crise desencadeada decorrerá da deterioração dos fundamentos macroeconômicos.

9. No Brasil, em particular, o retorno ao mercado financeiro internacional se deu nos anos 1990.

10. A crítica à conversibilidade da conta de capitais e financeira do balanço de pagamentos pode ser vista em Edison et al. (2002), Prasad et al. (2003), Rogoff (2002) e Dooley et al. (2003), entre outros autores. É válido ressaltar que Franco (1999), apesar de defender a forte administração da taxa de câmbio ao longo do Plano Real, também é um crítico à conversibilidade da conta de capitais e financeira do balanço de pagamentos.

11. A análise da supervalorização cambial ao longo do Plano Real já foi realizada por diversos autores, o que poderia dispensar a presente discussão. No entanto, o comportamento dessa variável é essencial para compreender a evolução dos fundamentos macroeconômicos brasileiros na segunda metade da década de 1990. Em conseqüência, optou-se pela construção da presente análise. Além disso, a discussão subjacente relativa aos efeitos dos preços dos bens comercializáveis e não comercializáveis sobre a supervalorização cambial traz informações importantes sobre o caso brasileiro.

12. Os dados e cálculos referentes à taxa de câmbio real não foram colocados no presente artigo em decorrência da exigüidade de espaço. Tais dados, no entanto, podem ser requisitados aos autores.

13. A análise do relacionamento entre a valorização da taxa de câmbio real e a deterioração da balança comercial ao longo do Plano Real pode ser vista em Miranda (1999) e Silva Andrade e Torrance (2000).

14. Cálculos realizados a partir de dados do Boletim do Banco Central do Brasil sobre a dívida externa total (dados anuais).

15. Havia o aumento simultâneo de ativos (reservas internacionais) e de passivos (dívida interna).

16. Não é objetivo deste artigo realizar uma análise detalhada dos fatores que causaram a ampliação da dívida brasileira, mas não se pode desmerecer a importância do reconhe- 
cimento e assunção de dívidas prévias. Eram os chamados “esqueletos", tais como aqueles referentes aos bancos estaduais e às dívidas de estados e municípios.

17. A esse respeito, ver Hamilton e Flavin (1986, p. 815-816).

18. Trehan e Walsh realizaram o teste de estacionariedade sobre a primeira diferença do estoque de dívida pública partindo do pressuposto de que essa variável transformada é igual ao déficit nominal. Porém, observando-se o caso brasileiro, as variáveis não demonstraram essa igualdade. Portanto, o teste será empreendido a partir dos dados para o déficit nominal.

19. Há uma ressalva na aplicação do teste. Ao invés do deficit nominal, optou-se pela utilização do déficit operacional por causa das distorções derivadas do processo inflacionário ainda presente nos anos 1994 e 1995.

20. Realizadas as estimações, verificou-se que os erros das equações referentes aos déficits operacional e primário mostraram-se serialmente correlacionados. Em conseqüência, também foi construído o teste de raiz unitária de Phillips-Perron, como sugerem Hamilton (1994) e Heij et al. (2004).

21. Outra maneira de avaliar as operações de crédito do setor público é a mensuração dessa variável como proporção das operações de crédito totais da economia. Os dados demonstram que essa relação caiu desde o início do Plano Real. Houve, a partir do quarto trimestre de 1995, uma retomada no ritmo de crescimento dessa variável, porém a níveis inferiores àqueles que prevaleciam em 1993, ou seja, antes da instalação do plano de estabilização econômica. Ao final de 1997, contudo, a relação passa a ser novamente declinante. Portanto, em grande medida, os dados mimetizam os resultados obtidos para as operações de crédito do setor público como proporção do PIB.

\section{REFERÊNCIAS BIBLIOGRÁFICAS}

ANDRADE, J. P.; DIVINO, J. A. C. A. Currency crises in Brazil: the role of the fundamentals and the rumors. Applied Economics, v. 33, p. 887-898, 2001.

ANDRADE, J. P.; SILVA M. L. F.; CARNEIRO, F. G. Contrasting monetary policies within the Mercosur experiment. Economia Aplicada, v. 4, p. 223-251, 2000.

ARBEX, M. A.; FONTES, R. Credibilidade das políticas econômicas no Brasil: uma análise empírica do período 1991-1998. Economia Aplicada, v. 3, p. 23-45, 1999.

ASSIS, M. de. A origem das crises financeiras internacionais: fracos fundamentos ou puro contágio? Uma análise empírica. Economia Aplicada, v. 6, p. 463-483, 2002.

AVERBUG, A.; GIAMBIAGI, F. A crise brasileira de 1998-1999: origens e conseqüências. Texto para Discussão, Rio de Janeiro: BNDES, n. 77, 2000.

BRASIL, BANCO CENTRAL DO BRASIL. Notas metodológicas do balanço de pagamentos. Notas técnicas do Banco Central do Brasil, Brasília: Departamento Econômico, Banco Central do Brasil, n. 1, 2001. 
CALVO, G. A.; VÉGH, C. A. Exchange-rate based stabilisation under imperfect credibility. In: FRISCH, H.; WORGOTTER, A. Open-economy Macroeconomics. Londres: MacMillan Press, 1993.

- Inflation stabilization and BOP crises in developing countries. In: TAYLOR, J.; WOODFORD, M. Handbook of Macroeconomics. Amsterdam: North Holland, 1998.

DOOLEY, M. P.; FOLKERTS-LANDAU D.; GARBER, P. An essay on the revived Bretton Woods. NBER Working Paper, Cambridge, Mass.: National Bureau Economic Research, n. 9.971, 2003.

EDISON, H.; KLEIN, M.; RICCI, L.; SLOK, T. Capital account liberalization and economic performance: a review of the literature. IMF Working Paper, Washington, D. C.: International Monetary Fund, n. 120, 2002.

FLOOD, R. P.; PETER, M. G. Collapsing exchange rate regimes: some linear examples. Journal of International Economics, v. 17, p. 1-13, 1984.

FLOOD, R. P.; PETER, M. G.; KRAMER, C. Collapsing exchange rate regimes: another linear example. Journal of International Economics, v. 41, p. 223-234, 1996.

FORBES, K.; RIGOBON, R. Measuring contagion conceptual and empirical issues. In: CLAESSENS, S.; FORBES, K. International Financial Contagion. Kluwer Academic Press: Boston, 2001.

FRANCO, G. H. B. O real e o câmbio: observações à margem da experiência. In: FRANCO, G. H. B. O desafio brasileiro: ensaios sobre desenvolvimento, globalização e moeda. São Paulo: Editora 34, 1999.

Hamilton, J. D. Time Series Analysis. Princeton, New Jersey: Princeton University Press, 1994.

MARJORIE, A. F. On the limitations of government borrowing: a Framework for empirical testing. The American Economic Review, v. 76, p. 808-819, 1986.

HEIJ, C.; DE BOER, P.; FRANSES, P. H.; KLOEL, T.; VAN D., HERMAN K. Econometric Methods with Applications in Business and Economics. [S. 1.]: Oxford University Press, 2004.

KRUGMAN, P. A model of balance-of-payments Crises. Journal of Money, Credit and Banking, v. 11, p. 311-325, 1979.

MENEZES, A. C.; MOREIRA, T. B. S. O modelo de Krugman explica a crise cambial brasileira em janeiro de 1999? Revista Análise Econômica, v. 36, p. 85-104, 2001.

MENEZES, A. C.; MOREIRA T. B. S.; SILVA E SOUZA, G. Credibilidade e crises cambiais: uma aplicação do modelo de velasco. Economia Aplicada, v. 9, p. 445-463, 2005.

MIRANDA, M. C. Crises cambiais e ataques especulativos no Brasil: janeiro de 1982 a janeiro de 1999. (Dissertação de Mestrado). Brasília: Departamento de Economia, Universidade de Brasília, 1999.

MÜNCH, I. P. Bandas de câmbio e expectativas de desvalorização: um teste de credibilidade aplicado a Brasil, México, Rússia, Venezuela, Tailândia e Hong Kong. Revista Brasileira de Economia, v. 52, p. 637-673, 1998. 
OBSTFELD, M. Balance-of-payments crises and devaluation. Journal of Money, Credit and Banking, v. 16, p. 208-217, 1984.

. Rational and self-fulfilling balance-of-payments crises. The American Economic Review, v. 76, p. 72-81, 1986.

. The logic of currency crises. Cahiers Economiques et Monétaires (Banque de France), v. 43, p. 189-213, 1994.

ÖTHER, I. E; PAZARBASIOGLU, C. Speculative attacks and currency crises: the Mexican experience. IMF Working Paper, Washington, D. C.: Fundo Monetário Internacional, n. 95, p. 112, 1995.

PASTORE, A. C.; PINOTTI, M. C. Câmbio flutuante, inflação e crescimento econômico. In: REIS VELLOSO, J. P. A crise mundial e a nova agenda de crescimento. Rio de Janeiro: José Olympio, 1999.

Inflação e estabilização: algumas lições da experiência brasileira. Revista Brasileira de Economia, v. 53, p. 3-40, 1999a.

PRASAD; ESWAR; ROGOFF K.; SHANG-JIM, W.; KOSE, M. A. Effects of Financial Globalization on Developing Countries: some empirical evidence. Washington, D. C.: International Monetary Fund, 2003.

REBELO, S.; VÉGH, C. A. Real effects of exchange rate-based stabilization: an analysis of competing theories. In: BERNANKE, B. S.; ROTEMBERG, J. NBER Macroeconomics Annual, MIT Press, 1995.

ROGOFF, K. Rethinking capital controls: when should we keep an open mind? Finance and Development, v. 39, 2002.

SCHWARTSMAN, A. A crise cambial e o ajuste fiscal. Revista de Economia Política, v. 19, p. 5-29, 1999.

SILVA, M. L. F.; ANDRADE, J. P.; TORRANCE, T. S. Fundamentals versus external shocks: Brazil's growing exposure to currency crises. International Advances in Economic Research, v. 6, p. 192-209, 2000.

SOARES, F. A. R. A administração da taxa de câmbio durante o Plano Real e os fundamentos econômicos do Brasil. (Tese de Doutorado). Brasília: Departamento de Economia, Universidade de Brasília, 2006.

SOARES, F. A. R.; PINTO, M. B. de P.; MOREIRA, T. B. S. Análise dos desequilíbrios cambiais a partir do Índice de Pressão de Fundamentos: a experiência brasileira do anos noventa, 2006. (mimeo.)

TREHAN, B.; WALSH, C. E. Testing intertemporal budget constraints: theory and applications to U.S. federal budget and current account deficits. Journal of Money, Credit and Banking, v. 23, p. 206-223, 1991.

VELASCO, A. Fixed exchange rates: credibility, flexibility and multiplicity. European Economic Review, v. 40, p. 1.023-1.035, 1996. 